East African Medical Vol. 77 No 1 January 2000

HEPATITIS B AND C VIRUS INFECTIONS AND LIVER FUNCTION IN AIDS PATIENT AT CHRIS HANI BARAGWANATH HOSPITAL, JOHANNESBURG

H. Lodenyo, MBChB, MMed. (Int Medicine) (NBI) Cert in Gastroenterology (Wits) Research Officer, Centre for Clinical Research, Kenya Medical Research Institute, B. Schoub, PhD. Director, National Institute of Virology, RSA. R. Ally, MBChB, FCP (SA) Principal Medical Officer and Gastroenterologist, Chris Hani Baragwanath Hospital, Johannesburg, S. Kairu MBChB, MMed. Physician - Forces Memorial Hospital, Kenya and Registrar, African Institute of Digestive Diseases, Johannesburg. I. Segal FRCP, Emeritus Professor of Medicine and Gastroenterology, University of Witwatesrand and Head, Division of Gastroenterology, Chris Hani Baragwanath Hospital and Head, African Institute of Digestive Diseases, Johannesburg, South Africa.

Request for reprints to: Professor I. Segal, Head, Division of Gastroenterology, University of Witwatersrand, Johannesburg, P.O. Bartsham, 2013, South Africa

\title{
HEPATITIS B AND C VIRUS INFECTIONS AND LIVER FUNCTION IN AIDS PATIENTS AT CHRIS HANI BARAGWANATH HOSPITAL, JOHANNEBURG
}

\author{
H. LODENYO, B. SCHOUB, R. ALLY, S. KAIRU and I. SEGAL
}

\begin{abstract}
Background: Impaired liver function tests and co-infection with hepatitis viruses in AIDS patients are common in western countries.

Objective: To assess liver function and prevalence of co-infection with hepatitis $B$ and hepatitis $\mathrm{C}$ viruses in AIDS patients at Chris Hani Baragwanath Hospital.

Design: A prospective study.

Setting: Chris Hani Baragwanath Hospital, Johannesburg, South Africa.

Patients: One hundred consecutive patients with AIDS admitted to Chris Hani Baragwanath Hospital.

Results: There were 52 males and 48 females aged 16 to 54 years (mean + SD: $34.6+$ 7.5 years). The results of laboratory test were as follows: LFTs: bilirubin $11.8(+15.6) \mu \mathrm{mol} /$ l; AST: 79.6 $( \pm 116.6)$ iu/L; alkaline phosphatase: $204.3( \pm 237.4) \mathrm{i} \mu / \mathrm{L}$; albumin: $23.9( \pm 6.2)$ g/l; CD4+ Iymphocytes: 141.5 ( \pm 168.6$) \mu \mathrm{l}$; CD8+: 666.9 ( \pm 618.3$) \mu \mathrm{l}$; HBV - HbsAg: 6 (6\%); HbsAg + eAg: 3 (3\%); previous disease (Anti HBs and/or anti HBc): 35\%, HCV: 1(1\%). Conclusion: Liver function tests were impaired in the majority of patients with AIDS (93\%) in our setting. Evidence of previous and present $\mathrm{HBV}$ infection was present in $41 \%$. This is different from what is observed in western countries $(90-95 \%)$. The results also suggest that patients here acquired HBV infection while still immuno competent. HCV infection was rare.
\end{abstract}

\section{INTRODUCTION}

Both HIV and HBV infections share common modes of transmission, predominantly blood exposure and high risk sexual activity. From studies conducted in western countries, 90-95\% of patients with AIDS had serological evidence of present or past HBV infection( 1,2). Hepatitis $C$ virus infection is also transmitted by parenteral routes and co-infection with HIV among patients with history of intravenous drug use (IVDU) or blood transfusion are common $(3,4)$. However, it is less clear whether HCV, like HIV is sexually transmitted. Wright et al(4) study from San Francisco, California found $11.7 \%$ prevalence of $\mathrm{HCV} / \mathrm{HIV}$ co-infection which could not be accounted for by IVDU or blood transfusion compared to one per cent in the HIV negative patients.

Previous studies in western countries indicate that up to $90 \%$ of patients with AIDS had abnormalities of their liver enzymes at presentation(5-10). Aetiological factors were multiple ranging from infections, neoplasms to medications(10). Neither type of enzyme abnormality could predict a particular infection, neoplasm or drug use $(8,11)$.

Between 12 and $35 \%$ of South Africans are infected with HIV and between 40 and $60 \%$ of admissions in medical wards in State hospitals have HIV-infection(12). From available statistics here, it has been observed that $40 \%$ of our HIV patients have impaired liver transaminases. Reports from the National Institute of Virology of South Africa, also show that eight to fifteen per cent of South African blacks are HBV carriers (HbsAg positive) and three to five per cent have antibodies to $\operatorname{HCV}(12)$.

Against this background, we set out to determine the prevalence of HBV and HCV serological markers as well as the evaluation of liver function and $\mathrm{T}$ cell Iymphocyte subsets (CD4+/CD8+) in AIDS patients admitted to $\mathrm{CHB}$ Hospital.

\section{MATERIALS AND METHODS}

One hundred consecutive patients with serologic evidence of HIV-infection who fulfilled the 1993 revised classification system for HIV-infection and the expanded AIDS surveillance 
Table 1

Liver function tests, globulins and $T$ cell subsets

\begin{tabular}{|c|c|c|c|c|c|c|c|c|c|c|c|c|}
\hline & \multicolumn{3}{|c|}{ Bilirubin } & \multicolumn{3}{|c|}{$\begin{array}{l}\text { Liver function tests } \\
\text { Serum enzymes }\end{array}$} & \multicolumn{5}{|c|}{ Serum proteins } & \multirow{2}{*}{$\begin{array}{c}\begin{array}{c}\mathrm{T} \text { cell } \\
\text { Subsets }\end{array} \\
\begin{array}{c}\mathrm{CD} 8+ \\
\mathrm{mm}^{3}\end{array}\end{array}$} \\
\hline & $\begin{array}{r}\text { Total } \\
\mu \mathrm{moi} / \mathrm{L}\end{array}$ & $\begin{array}{c}\text { Direct } \\
\mu \mathrm{mol} / \mathrm{L}\end{array}$ & $\begin{array}{l}\text { Indirect } \\
\mu \mathrm{mol} / \mathrm{L}\end{array}$ & $\begin{array}{l}\text { AST } \\
\text { lu.L }\end{array}$ & $\begin{array}{l}\text { ALT } \\
\text { iu.L }\end{array}$ & $\begin{array}{l}\text { ALK Phosp } \\
\text { lu/L }\end{array}$ & $\begin{array}{l}\text { GGT } \\
\mathrm{Iu} / \mathrm{L}\end{array}$ & $\begin{array}{c}\text { Total } \\
\mathrm{g} / \mathrm{L}\end{array}$ & $\begin{array}{l}\text { ALB } \\
\mathrm{g} / \mathrm{L}\end{array}$ & $\begin{array}{c}\text { GLos } \\
\text { g/L }\end{array}$ & $\begin{array}{l}\mathrm{CD} 4+ \\
\mathrm{mm}^{3}\end{array}$ & \\
\hline Mean & 11.8 & 5.99 & 5.8 & 79.6 & 44.6 & 204.3 & 105.5 & 78.7 & 23.9 & 55.1 & 141.6 & 666.9 \\
\hline SD & 15.6 & 21.1 & 4.5 & 116.6 & 72.6 & 237.4 & 119.6 & 15.6 & 6.2 & 14.6 & 168.6 & 618.3 \\
\hline $\begin{array}{l}\text { Normal values } \\
\% \text { with }\end{array}$ & $5.1-17$ & $1.7-5.1$ & $3.4-12$ & $0-35$ & $0-35$ & $3.0-120$ & $7-40$ & $55-80$ & $32-52$ & $20-35$ & $500-2010$ & $250-990$ \\
\hline abnormal results & $14 \%$ & & & $66 \%$ & $36 \%$ & $56 \%$ & $78 \%$ & $44 \%$ & $86 \%$ & $93 \%$ & & \\
\hline
\end{tabular}

Table 2

Hepatitis $B$ virus and hepatitis $C$ serological markers

\begin{tabular}{|c|c|c|c|c|c|}
\hline \multirow[b]{2}{*}{$\begin{array}{l}\text { Serological } \\
\text { Markers }\end{array}$} & \multicolumn{3}{|c|}{ Hepatitis B virus markers HCV } & \multirow[b]{2}{*}{ Anti $\mathrm{HBc}$} & \multirow[b]{2}{*}{ Anti $\mathrm{HCV}$} \\
\hline & $\mathrm{HbsAg}$ & Anti HBs & $\mathrm{HBeAg}$ & & \\
\hline No & 6 & 35 & 3 & 41 & 1 \\
\hline$\%$ of total & 6 & 35 & 3 & 41 & 1 \\
\hline
\end{tabular}

case definition for adolescents and adults( 13) criteria for AIDS, admitted to the medical wards in CHB Hospital in May 1999. Informed consent was obtained from the patients. The following tests were carried out: (i) liver function tests, namely, alkaline aminotransferase (ALT), aspartate aminotransferase (AST), alkaline phosphatase (Alk Phosph), gamma glutamyl transferase (GGT), bilirubin levels, serum albumin and total serum proteins, using standard routine spectrophotometric methodology; (ii) $\mathrm{T}$ Iymphocyte subsets CD4+ and CD8+ using flow cytometry; (iii) hepatitis $\mathrm{B}$ virus markers: hepatitis B surface antigen (HbsAg), hepatitis e antigen ( $\mathrm{HBeAg}$ ), hepatitis B surface antibody (Anti $\mathrm{HBs}$ ), hepatitis B core antibody(AntiHBc)using Abbott's diagnostic kits and; (iv) hepatitis $\mathrm{C}$ virus antibody (Anti $\mathrm{HCV}$ ) using standard third generation ELISA kits.

\section{RESULTS}

Fifty two males and 48 females were studied. The age range was 16 to 54 years (Mean \pm SD; $34.6 \pm$ 7.5 years). The liver function tests, serum proteins and $\mathrm{T}$ cell subset counts are as shown in Table 1 . Ninety seven per cent of patients had elevated globulin and/ or reduced serum albumin, $70 \%$ had elevated AST and/ or ALT and $78 \%$ had elevated GGT. CD4+ counts were generally low and CD8+ lymphocyte counts were within or above the normal levels in the majority of patients. The liver enzymes suggest there was a preponderance towards hepatobiliary obstruction relative to hepatocyte injury. Table 2 shows the prevalence of HBV and HCV serological markers in our study population. The overall prevalence of present and past HBV viral infection was $41 \%$, with six patients carriers of $\mathrm{HBsAg}$ and three positive for $\mathrm{HBeAg}$. Hepatitis C virus antibodies were rare (one per cent). None of the patients had been vaccinated against HBV.

\section{DISCUSSION}

HIV, HBV and HCV share common modes of transmission, namely, blood exposure for all high risk sexual behaviour for HIV and HBV. The role of high risk sexual behaviour in $\mathrm{HCV}$ transmission is controversial. Our results show that HBV/HIV coinfection $(41 \%)$ is not as common as the western series of $90-95 \%(1,4,11)$ and HCV/HIV co-infection of one per cent much lower than the $11.7 \%$ found by Wright et al(4) in patients without a history of intravenous drug use. Fifteen per cent of those who had HBV-infection developed a HBsAg chronic carrier state and $50 \%$ of those with $\mathrm{HBsAg}$ had $\mathrm{HBeAg}$. This compares well with ten per cent HBsAg carrier rate and $66 \%$ of $\mathrm{HBeAg}$ positivity in those with HBsAg found by Rustgi et al (2). None of the patients with HBsAg had elevated bilirubin, two had slight elevation of AST, one ALT 
and one, both ALT and AST were minimally elevated. These findings also concur with those of Rustgi(2). The serological results suggest that most of the patients who developed HBV infection did so when they were still immunocompetent. Patients with immunodeficiency syndromes or those who are exogenously immunosuppressed are at an increased risk of developing the chronic HBsAg carrier state as shown among patients on renal dialysis who develop an HBV carrier rate of $60-90 \%(14)$. If these patients had developed HBV after developing immunodeficiency, a higher percentage might be expected to become chronic HBsAg carriers. The percentage of patients who were HBsAg carriers (six out of 41) is characteristic of the percentage of young adults infected with this virus who develop the chronic carrier state(15 - 16). During the course of HIV infection, the liver and the biliary tract often get affected with opportunistic infections, neoplasms or effect of drug therapy used in treatment(911). Ninety six per cent of our patients had a reduced serum albumin and/or an elevated globulin levels. At least one of the serum enzyme levels was elevated in $88 \%$ of the cases: GGT in $78 \%$, AST and/ or ALT in $70 \%$ and alkaline phosphatase in $56 \%$ of the cases. These high enzyme levels were more frequent than in previous studies(5-9). This could be due to the fact that most of our patients were in more advanced stages of their disease (CD4+ count $141.5 \pm 158.6$ / $\mathrm{mm}^{3}$ ). In the past, it was felt that in patients with AIDS or even early stages of HIV, chronic viral hepatitis was not likely to affect life expectancy or to cause a significant number of complications. However, as our ability to treat HIV infection improves, hepatitis viruses may emerge as important pathogens in patients with HIV infection. In conclusion, most of the patients evaluated were in advanced stages of AIDS and had impaired liver function tests. Evidence of past and present HBV infection was present in $41 \%$ of the patients. This is in contrast to the high levels observed in western countries. However, the HBsAg carrier rate in our study was similar to that observed in western countries. The results suggest that AIDS patients in Soweto and in western countries acquired HBV infection while still immunocompetent. HCV infection was rare being, one per cent compared with $11.7 \%$ found in the USA. This suggests that in our group of patients sexual transmission of $\mathrm{HCV}$ is not a major factor.

\section{ACKNOWLEDGEMENTS}

We wish thank the following: The patients who voluntarily agreed to participate in the study; Sunette Roos for secretarial services; H. Hassan and the rest of the laboratory staff for laboratory tests; Nursing staff in the medical wards of Chris Hani Baragwanath Hospital.

\section{REFERENCES}

1. Dove, L. and Wright T.L. Hepatitis/HIV co-infection infection with Hepatitis viruses in patients with Human Immunodeficiency virus. Medical Dilemma or Inconsequential coincidence. Adv. Gastroent. Hepat. Clin. Nutr. 1997; 1: 231-39.

2. Rustgi, V., Vinod, I.C. and Hoofnagle, J., Gevin, et al. Hepatitis B virus infection in acquired immunodeficiency syndrome. Ann. Intern. Med. 1984; 101: 795-7.

3. Alter, M.J., Hadler, S.C., Judson, F.N., Mares, A., Alexander, T., Hu P.Y. and Miller, J.K. et al. Risk factors for acute non-A non-B hepatitis in the United States and association with hepatitis $\mathrm{C}$ virus infection. J. Amer. Med Ass. 1990; 264: 2231-35.

4. Wright, T.L., Honnander, H., Pu X., Held, M.J., Lipson, P., Quan, S., Polito, A., Thaler, M.M., Bacchetti, P. and Scharschmidt, B.F. Hepatitis C in HIV infected patients with and without AIDS: prevalence and relationship to survival. Hepatology. 1994; 20: 1152

5. Glasgow, B.J., Anders, K., Layfield, R.L., Steinsapir, I.C.D., Gitmick G. and Levin K.J. Clinical and Pathological findings of the liver in the acquired immunodeficiency syndrome (AIDS). Amer. J. Clin. Pathol. 1985; 83: 582-8.

6. Dworkin, B.M., Stahl, R.E. and Giardina, M.A. et al. The liver in acquired immune deficiency syndrome: Emphasis on patients with intravenous drug abuse. Amer. J. Gastroenterol. 1987; 82: 231-6.

7. Nakanuma, Y., Liew, C.T., Peter, R.L. and Gonndarajan $\mathrm{S}$. Pathologic features of the liver in the acquired immune deficiency syndrome (AIDS). Liver. 1986; 6: 158-66.

8. Lebovics, E., Thung, S.N., Schaffner, F. and Radensky, P.W. The liver in the acquired immunodeficiency syndrome: a clinical and histologic study. Hepatology 1985; 5: 293-8.

9. Maurizio, B. Hepatobiliary complications in patients with Human Immunodeficiency virus infection. Amer. J. Med. 1992; 92: 40411.

10. Poles, M.A., Lew, E.A.and Dieterich, D.T.Gastroent. Clin. N. Amer. 1997; 26: 291-321 .

11. Comer, G.M., Mukherjee, S., Holness, L.G. and Clain, D.J. Liver biopsies in the acquired immune deficiency syndrome. Influence of endemic disease and drug abuse. Amer. J. Gastroenterol. 1989: 84: 1525 - 31.

12. Statistics from National Institute of Virology of South Africa, 1999.

13. Fauci, A.S. and Lane, H.C. Human Immunodeficiency Virus (HIV) Disease: Aids and Related Disorders. Harrison Principles of Internal medicine 14th Edition, 1998; vol. 2: 1791-1856.

14. London, W.T., Drew, J.S., Lustbacler, E.D., Werner, B.G. and Blumberg, B.S. Host responses to Hepatitis B infection in a chronic dialysis unit. Kidney int. 1977; 12: $51-8$.

15. Redeker, A.G. Viral hepatitis, Clinical aspects. Amer. J. Med. Sci. 1975; 270: 9-16.

16. Buchel, E. Management of Acute Hepatitis. Doctors own Medical Education series. 1999: 4: 1-2. 